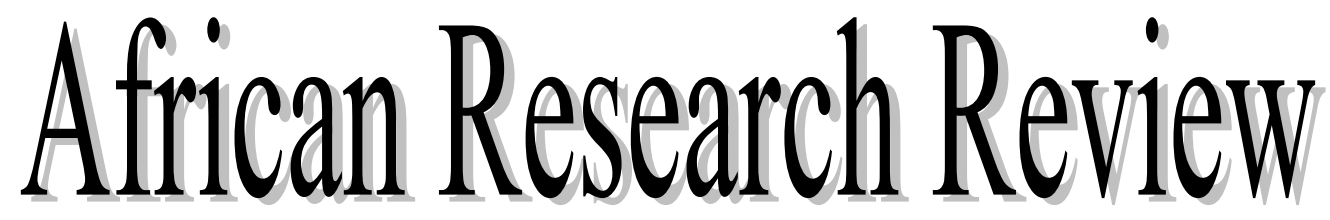

AN INTERNATIONAL MULTI-DISCIPLINARY JOURNAL, BAHIR DAR, ETHIOPIA

AFRREV VOL. 11 (4), SERIAL NO. 48, SEPTEMBER, 2017:156-173

ISSN 1994-9057 (Print)

ISSN 2070-0083 (Online)

DOI : http://dx.doi.org/10.4314/afrrev.v11i4.13

\title{
Analysis of the Impact of External Debt on Economic Growth in an Emerging Economy: Evidence from Nigeria
}

\author{
Paul, Ndubuisi \\ Department of Banking and Finance, \\ Abia State University, Uturu \\ Phone: $+\mathbf{2 3 4 8 0 5 1 8 2 1 0 7 8}$ \\ E-mail: pauloabsu2017@gmail.com
}

\begin{abstract}
This study set out to analyse the impact of external debt on economic growth of Nigeria. Data for the study are collected from secondary sources. The variables on which data are collected include; Gross Domestic Product, External debt services, external debt stock, external reserve, and exchange rate. The scope of the study covers the period from 1985 to 2015. Data are analysed using the ordinary least square regression, ADF unit root test, Johansen cointegration and error correction test. Findings reveal that debt service payment has negative and insignificant impact on Nigeria's economic growth while external debt stock has positive and significant effect on Nigeria's growth index. The control variables: external reserve and exchange rate have positive and significant effect on growth. The ADF unit root test shows that all the variables are not stationary at levels but at first difference. Johansen cointegration test shows long-run relationship between external debt and growth index (GDP). It also showsed that the variables have at least one common stochastic trend driving the relationship between them. The causality test indicates unidirectional causality between external debt and GDP. From the findings, the study recommended that government should apply external loans to infrastructural development; improve business environment through legislation; initiate proper debt management policies and substitute external borrowing for human capital development.
\end{abstract}

Key Words: Economic growth, external debt, dependency theory, debt servicing; external reserve, exchange rate

Copyright () International Association of African Researchers and Reviewers, 2006-2017: www.afrevjo.net.

Indexed African Journals Online: www.ajol.info 


\section{Introduction}

The act of borrowing creates debt. Debt, therefore, refers to the resources of money in use in an organization which is not contributed by its owners and does not in any other way belong to them (Udoka and Ogege, 2012). Public debt can either be domestic or external debt. Domestic debts are those debts incurred within the country while external debt are those debts incurred outside the shore of the country. Udoffia and Akpanah (2016) defined external debt as packages that consist of a combination of financial, technical vis-a-vis managerial requirements emanating from outside the country, aimed at supporting economic growth and development and are repayable at determined future date in foreign currency. External debt is a major source of public receipts. The accumulation of external debt should not signify slow economic growth. It is a country's inability to meet its debt obligation compounded by the lack of information on the nature, structure and magnitude of external debt.

The economy of Nigeria had a magnificent growth following the oil boom of the 70s. Nigeria foreign debt profile witnessed a dynamic change after 1978 following the world oil glut. Much pressure was then exerted on government finances and it became necessary to borrow for balance of payment support and financing of developmental project.

The first major federal government borrowing of US \$1 billion from the international capital market (ICM) was referred to as "Jumbo loan" increasing her total external debt to $\$ 22$ billion. The condition worsened between 1981 and 1982 as various government agencies and state governments resorted to deficit budgeting partly financed through external loans secured from private sources under stiffen conditions (CBN, 1989). The Debt Management Office (DMO) annual report and account (2001) reflected a 13.8\% fall of official debt sources in favour of the private debt sources which rose again to an average of $82 \%$. Trade arrears emerged by the end of 1982 constituting a large portion of the total external debt of the nation. The jumbo loan of 1987 was supported by the promulgation of decree No 30 of the 1978 which limited the external loans that the Nigerian government could raise to $\$ 5$ billion.

Nigeria's external debt increased so much due to excess borrowing from international agencies and countries at non-concessional interest rate as a result of the decline in oil earnings from the late 70's and the emergence of high trade arrears due to inability of the country to either easily produce or foot the bills of importation of the needed goods and services. Nigeria economic growth and development has been highly discouraging despite the huge external loan profile before the year 2000. Within the 80s, the country experienced the most economic recession with declining growth rate, hyperinflation, and high unemployment rate, disequilibrium in balance of payment, industrial decadence, poor infrastructure and serious external debt burden. The poverty rate of the country stood at $65 \%$ and the country was classified as one of the weakest economies of the world on per capital basis.

The issue of Nigeria's public debt became important in recent times especially prior to the period of the debt forgiveness because of its magnitude and the amount, which was required to service such debts as well as its attendant possible effects on different operating sectors of the economy especially the banking sector and the growth of the economy at large. In 2005, Nigeria external debt was US\$34 billion (an equivalent of

Copyright () International Association of African Researchers and Reviewers, 2006-2017: www.afrevjo.net.

Indexed African Journals Online: www.ajol.info 
N2.7 trillion) of which about $\$ 28$ billion or $85 \%$ was owed to the Paris club of fifteen creditor nations (Emmanuel, 2012). Although the government successfully negotiated debt forgiveness and exit from the Paris club and London club of creditors resulting in the fall of external debt from N2.7trillion in 2005 to less than N451.46billion in 2006, there was however a spike in the external loan to N1.03trillion in 2011 andN2.Ill trillion by 2015 .

The federal government's intention to borrow \$29.9 billion, would push Nigeria's external debt stock which stood at $\$ 11.262$ billion as at June 2016 to $\$ 41.162$ billion after three years when the borrowing plan would have Been fully executed.

\section{Statement of Problem}

According to Debt Management Office (DM0, 2006), Nigeria's external debt profile has become as a source of concern to everyone as over $\$ 32$ billion were used for debt services between 1985 and 2001. Apparently, the huge debt overhang did not translate into meaningful economic growth as the nation was considered a developing economy with a per capita GDP of less than $\$ 5$. Despite the accumulated debt and debt relief that was granted around 2005 and 2006, basic infrastructure remains in poor state while poverty remained an average of $65 \%$ of the citizen which questions the need for external debt and subsequent benefit for the growth of the Nigerian economy.

The debt overhang models gave the impression that large debt stocks lower growth by partly reducing investment with a resultant negative effect on poverty. Invariably, debt overhang relief should trigger economic growth; have stimulating effect on investment, development affects per capital income positively which is prerequisite for poverty reduction. Could this be said to be real in the Nigeria context or situation? Has this relief suffered from macroeconomic instability, policies that distort economic incentives or sizable adverse shocks?

Prior to the relief, according to Soludo (2003), the country was on the wrong side of the debt-laffer-curve, with debt crowding out investment and growth. After the relief, what could still be crowding out investment and growth in Nigeria, and still propelling the government into more indebtedness? It is against this backdrop that the researcher intends to investigate the impact of external debt on economic growth in Nigeria. Using exchange rate and external reserve as control variables.

\section{Theoretical Framework}

This study, adopted dependency theory to explain the nature of the relationship between the countries of the world and the factors that have facilitated dependency of one group of countries on the other. Countries of the world have been sharply divided along economic prosperity. Countries that are economically buoyant and politically stable are termed Developed Countries and, on the other hand, countries that are economically backward are tagged Developing Countries or commonly referred to as 'Third World Countries'.

Andre Gunder Frank, theorized elaborately on Brazil and Latin American countries. The situation in Africa of necessity needs to situate development within the international perspective, and, particularly posited within the context of dominance and the character of the manoeuvrings which is as essential to a proper understanding of

Copyright (C) International Association of African Researchers and Reviewers, 2006-2017: www.afrrevjo.net.

Indexed African Journals Online: www.ajol.info 
the nature of underdevelopment $\mathrm{s}$ a thorough knowledge of the chains of dependency (Adejuwon, James \& Adebayo, 2010).

The dependency theory seeks to establish the factors that have propelled or contributed to the development of the underdeveloped countries. This theory is predicated on the assumption that resources flow from a "periphery" of poor and underdeveloped states to a "core" of wealthy states, enriching the latter at the expense of the former. It is a central contention and standpoint of dependency theory that poor states are impoverished and rich ones enriched by the way poor states are integrated into the "world system" (Todaro, 2003; Amin, 1976).

Dependency theory states that the poverty of the countries in the periphery is not because they are not integrated or fully integrated into the world system as is often argued by free market economists, but because of how they are integrated into the system. There are two schools of thought with different standpoints on the issue. One of these is the bourgeois scholars and the second one is radical scholars of the neoMarxian political economy (Adejuwon, James \& Adebayo, 2010). To the bourgeois scholars, the underdevelopment and the consequent dependence of most of TWCs is as a result of their internal contradictions. To them, this problem can be explained by their lack of close integration, diffusion of capital, technology and institutions, bad leadership, corruption, mismanagement, etc. (Momoh and Hundeyin, 1999). The standpoint views the under-development and dependency of the TWCs as internally inflicted rather than externally inspired. To this school of thought, a way out of the problem is for TWCs to seek foreign assistance such as aid, loan, investment, etc. and allow unhindered operations of the Multinational Corporations (MNCs).

Due to the underdeveloped nature of most TWCs, they are dependent on the West for virtually everything ranging from technology, aid, technical assistance, loan, to culture, etc. The dependent position of most TWCs has made them to be susceptible and vulnerable to the machinations of the Western metropolitan countries and Breton Woods institutions (Ajayi, 2000). Whether to ascribe the underdevelopment and dependency of the Third World to the eloquent submission of the bourgeois scholars or to subscribe to the europhoric explanations of the neo-Marxian theorists, the fact is that the dependency theory explains in details the factors responsible for the position of the Third World Countries and their constant demand for loan, and continuous reliance on foreign loan for developmental efforts.

\section{Empirical Literature}

In a study of the impact of external debt economic growth in Nigeria, Ezike and Mojekum (2011), found that external debt was positive while debt service was negative. This was because debt capital adds to capital formation and positively impacted on economic growth. On the other hand, debt-service ratio reflects capital outflow and consequently deteriorates the performance of a country and thus reduces real GDP. It also confirms the theoretical expectations that debt service diverts resources away from the debtor country. Since total debt stock depicts a positive relationship in the results instead of a negative relationship and statistically significant at all the levels, they therefore concluded that total debt stock, less debt service, still leaves a robust positive balance, to enhance capital accumulation that positively impacts economic growth.

Copyright (C) International Association of African Researchers and Reviewers, 2006-2017: www.afrrevjo.net.

Indexed African Journals Online: www.ajol.info 
In a related study, Adesola (2009) focused on debt servicing and economic growth in Nigeria, using ordinary least square multiple regression method to determine whether debt payment to Multilateral Financial creditors, Paris Club creditors, London Club creditors, Promissory notes holders and Other creditors (Non-Paris Creditors) have inverse relationship with gross domestic product (GDP) and gross fixed capital formation at current prices (GFCF) from 1981 to 2004. The study revealed that debt payment to London Club creditors, Paris Club creditors, Promissory notes holders and other creditors have significant impact on the GDP and GFCF. Debt payment to Paris Club creditors and debt payment to promissory notes holders/are positively related to GDP and GFCF, while debt payment to London Club creditors and other creditors showed a negative significant relation to GDP and GFCF.

Ezeabasili, Isu, and Mojekwu, (2011) investigated the relationship between Nigeria's external debt and economic growth between 1975 and 2006 applying econometric analyses. The result of the error correction estimates revealed that external-debt has negative relationship with economic growth in Nigeria. They stated that Nigeria must be concerned about the absorptive capacity noting that consideration about low debt to GDP, low debt service/GDP capacity ratios should guide future debt negotiations.

In another study carried out by Nzekwu (2011) on the effect of external debt relief on sustainable economic growth and development in Nigeria using Chi-square, Regression and Correlation analysis to test the relationship between external and internal debt stock in relation to debt relief, he found that there is a relationship between external and internal debt stock in relation to debt relief, that debt relief affected the economic growth of the economy and that gradual reforms and investments will help bring back a healthy economy for the nation.

A study by Ekperiware and Oladeji (2012) examined the effect of external debt relief on economic growth in Nigeria using regression technique on quarterly time series of external debt, external debt service and real gross domestic product. Applying Chowtest to the regression result they found that there was a structural break in the relationship between economic growth and external debt in Nigeria during the period 1975 to 2005. The study concluded that the external debt relief made more resources available for economic growth in Nigeria and recommended a shift towards discretional concessional borrowing. It also identified external debt relief as a good option for poor unsustainable indebted countries as a way of making resources available for economic growth with the real sector being the focal point where value is created rather than impeding it with mismanagement and servicing debt.

Udoka and Ogege (2012) examined the extent of external debt crisis and its consequences on, economic development using data on the Nigerian economy for the period 1970 to 2010 . They employed the error correction modelling framework with co-integration techniques to test the relationship between per- capita GDP and other macroeconomic variables (foreign reserve, debt stock, investment, debt service payment). The test revealed that politics! instability may reduce the rate of development and other independent variables were responsible for the underdevelopment of the country. Hence, they recommended that, to avoid the crisis of economic development in Nigeria, external debt should be reduced to minimal level.

Copyright (C) International Association of African Researchers and Reviewers, 2006-2017: www.afrrevjo.net.

Indexed African Journals Online: www.ajol.info 
In a similar study on impact of external debt on selected macroeconomic indicators in Nigeria (1970 - 2010), Okoli (2014) used regression analysis to analyze the extent to which external debts and its service costs impacted on such macroeconomic indicators as Gross Domestic Product (GDP), total export, total revenue, total reserve and exchange rate. The study showed that debt utilization, diffusion in the management of loans, poor documentation and deficient external debt accounting and politics in the management of debt in the 80 's and 90's, our macroeconomic indicators had a negative trend thus aggravating debt burden at that period.

Obademi (2013) implemented time series data for the period 1970 - 2009 to analyze the relationship between external debt and economic growth. He concluded that the non-existence of long run relationship between external debt and economic growth in Nigeria indicates that increase in external debt could result to decrease in GDP. He therefore recommends, among other things that, government should strengthen policies that will improve better management of external debts in Nigeria.

Hameed et al (2013), examined the impact of real exchange rates on economic growth in South Africa. Using quarterly time series data for the period of 1994 to 2010. The Johansen cointegration and vector error correction model were applied to determine the impact of real exchange on economic growth in South Africa. Results of the study revealed that real exchange rates have a dampening long run impact on economic growth in South Africa. From the regression results, it was noted that undervaluation of the currency significantly hampers growth in the long run, whilst it significantly enhances economic growth in the short run. As such, the policy of depreciating exchange rates to achieve higher growth rates is only effective in the short run and is not sustainable in the long run. Based on the findings of this study, the authors recommend that misalignment (overvaluation and undervaluation) of the currency should be avoided at all costs.

Nwanne and Eze (2015) investigated the relationship between external public debt servicing and receipt and exchange rate fluctuations in Nigeria from 1981 to 2013. The findings of the study showed that external debt receipts and external debt servicing have positive short and long-run relationships with naira exchange rate fluctuations. The study concluded that whereas external public debt receipts affect exchange rate positively, external public debt servicing affects exchange rate negatively.

Hassan, Sule and Abu (2015) examined the effect of government debt on economic growth in Nigeria between 1986 and 2013 - using the ordinary least square method. The study revealed that the impact of government debt on economic growth over the period under review is insignificant - with external debt which has been enormous over the years contributing minimally to real gross domestic product. The findings of the study reveal that, if the course of consistent borrowing is not curbed, the economy will slump further: resorting to surplus budgeting, and igniting; increases in unemployment, decreases in total investment, falling reserves, increased exchange rate, higher inflation and consequently increased poverty. It is therefore recommended among others that borrowing should be a last recourse by the government to revitalize the economy, and if necessary, the loans should be sourced within the economy so that when the principal and interest on the loans are paid back, it will serve as a crowd-in-effect which in turn further accelerates economic activities in the country.

Copyright (C) International Association of African Researchers and Reviewers, 2006-2017: www.afrrevjo.net.

Indexed African Journals Online: www.ajol.info 
Ibi and Aganyi (2015) analysed the impact of external debt on economic growth in Nigeria. It uses the variance decomposition and impulse response from Vector AutoRegression (VAR). Based on the two-stage data processing, the result reveals that causation between external debt and economic growth is weak in the Nigerian context and external debt could thus not be used to forecast improvement or slowdown in economic growth in Nigeria. Hence, changes in GDP cannot be predicted with changes in external debt. For debt to promote growth in Nigeria, fiscal discipline and high sense of responsibility in handling public funds should be the watchword of Nigerian leaders.

Solomon (2016) investigated the impact of external debt on the Nigeria economy. Data was collected from the secondary source while the regression and granger causality methods of analysis were applied. The outcome of the regression analysis showed that external debt and external debt service have negative relationship with GDP. The granger causality test shows that GDP has a unidirectional causal relationship with external debt service which runs from GDP to external debt service, uni-directional causality exists between external debt and GDP which runs from external debt to GDP. It recommends that external debt should largely be for economic reasons rather than social or political reasons as this would increase the productivity of the nation.

Matthew and Mordecai (2016) examined the impact of public debt on economic development of Nigeria using annual time series data spanning 1986 to 2014. The study employed the Augmented Dickey-Fuller test, Johansen co-integral ion test, Error Correction Method (ECM) and the Granger Causality test. The Johansen co-integration test results revealed the presence of a long-run relationship among the variables viz; external debt stock, domestic debt stock, external debt servicing, domestic debt servicing and economic development (proxied with GDP per capita) in Nigeria. The ECM results revealed that external debt stock and external debt servicing have insignificant negative relationship with economic development in Nigeria, however, domestic debt stock has a direct and significant relationship with economic development while domestic debt service payment was significant but inversely related to economic development in Nigeria. The study recommended that the government should reduce the level of external debt it accumulates overtime, but domestic debt accumulation would contribute significantly to the development of the economy.

Udofia and Akpanah (2016) investigated the impact of external debt on economic growth in Nigeria. The issue was empirically examined using the cointegration test and the error correction test for Nigeria over the period 1980 to 2012. Findings from this study supported the traditional view between external debt and growth. Also, the study found the non-existence of debt overhang problem for Nigeria. It is recommended from the study that development activities in Nigeria be financed through increased export earnings spearheaded by export led growth strategy as well as investment in human capital as these can be the best alternative to external debt in the longrun.

\section{Methodology}

The research design adopted in this study is expost-facto as it involves time series data. This research work depended mainly on secondary data which are time series data sourced from CBN Statistical Bulletin from 1985-2015. 


\section{Specification of the Model}

The functional relationship between the dependent variable and proxies can be expressed as:

$$
\text { GDP }=f(D S P T \text { EXDT, EXR, FXR) }
$$

The model employed in the study includes the following:

$$
\mathrm{Y}=\quad \beta 0+\beta 1 \mathrm{X} 1+\beta 2 \mathrm{X} 2+\beta 3 \mathrm{X} 3+\beta 4 \mathrm{X} 4+\mathrm{U}
$$

That is, GDP $=\beta 0+\log \beta 1 \mathrm{DSPT}+\log \beta 2 \mathrm{DEXDT}+\log \beta 3 \mathrm{EXR}+\log \beta 4 \mathrm{FXR}+\mathrm{U}$ Gross

Where:

$\begin{array}{lll}\text { Gross Domestic Product } & = & \text { GDP } \\ \text { Debt Service Payment } & = & \Delta \text { SPT } \\ \text { External debt } & = & \text { EXDT } \\ \text { External Reserves } & = & \text { EXR } \\ \text { Foreign Exchange Rate } & = & \text { FXR } \\ \text { Stocahstic error term } & = & \text { U }\end{array}$

Appriori expectation: $\beta_{1}<0, \beta_{2}>0, \beta_{3}>0$ and $\beta_{4}>0$

\section{Estimation Procedure}

\section{Unit root Test}

In time series analysis, before running the cointegration test the variables must be tested for stationarity. For this purpose, we use the conventional ADF tests. Therefore, before applying this test, we determine the order of integration of all variables using unit root tests by testing for null hypothesis $H_{0}: \beta=0$ (i.e $\beta$ has a unit root), and the alternative hypothesis is $H_{1}: \beta<0$. This is to ensure that all the variables are integrated at 1(1) to avoid spurious result.

\section{Johansen Cointegration}

This study adopted a dynamic vector autoregressive regression (VAR) which explores cointegration. The essence is to observe the long run-and short dynamics. For instance, given a VAR with possible long run cointegration amongst a set of variables.

Therefore, we start with the Johansen co-integration equation which starts with the vector auto regression (VAR) of order $p$ is given by:

$y_{t}=\mu+A_{1} y_{t-1}+\cdots+A_{p} y_{t-P}+\varepsilon_{t}$

Where $y_{t}$ is a $(n \times 1)$ vector of variables uncler consiclertion in log form that are Integrated at order one-commonly denoted $1(1), n=5 A_{P}$ are the parameters to be estimated, $\varepsilon_{t}$ are the random errors. This (VAR) can be rewritten as;

$\Delta y_{t}=\mu+\Pi y_{t-1}+\cdots+\sum_{i=1}^{P=1} \Gamma_{i} y_{t-i}+\varepsilon_{t}$

Where, $\Pi=\sum_{i=1}^{p} A_{i}-1$ and $\Gamma_{i}=-\sum_{j=i+1}^{p} A_{j}$

The above equation is a pure Johansen Cointegration test. Gragory and Hansen 11996) noted that the Johansen test is a test for co-integration that allows for more than one

Copyright () International Association of African Researchers and Reviewers, 2006-2017: www.afrrevjo.net. 
co-integration relationship. If the coefficient matrix $\Pi$ has reduced rank $r<n$, then there exist $\mathrm{n} \times \mathrm{r}$ matrices of $\alpha$ and $\beta$ each with rank $r$ such that

$\Pi=\alpha \beta^{\prime}$

Where $r$ is the number of co-integrating relationship, the element is $\alpha$ is known as the adjustment parameters in the vector error correction model and each column of $\beta$ is a cointegrating vector. It can be shown that, for a given $r$, the maximum likelihood estimator of $\beta$ define the combination of $y_{t-1}$ that yield the $r$ largest canonical correlations of $\Delta y$ with $y_{t-1}$ after correcting for lagged differences and deterministic variables when present. The two-different likelihood ratio test of significance of these canonical correlations are the trace test and maximum eigen value test, shown respectively below

$\lambda_{\text {trace }}(r)=-T \sum_{i=r+1}^{n} \operatorname{In}\left(1-\hat{\lambda}_{l}\right)$

and

$\lambda_{\max }(r, r+1)=-\operatorname{TIn}\left(1-\hat{\lambda}_{r+1}\right)$

Here, $\mathrm{T}$ is the sample size and $\hat{\lambda}_{l}$ is the $i^{\text {th }}$ ordered eigen value from the $\Pi$ matrix in equation 3 or largest canonical correlation. The trace tests the null hypothesis that the number of $r$ co-integrating vector against the alternative hypothesis of $n$ co-integrating vector where $n i$ s the number of endogenous variables. The maximum eigenvalue tests the null hypothesis that there are $r$ cointegrating vectors against an alternative of $r+$ 1 (see Brooks 2002).

\section{Granger Causality Test}

To determine the direction of causality between the variables, we employ the standard Granger causality test (Granger, 1969). The test is based on error correction (ECM), which suggests that while the past can cause or predict the future, the future cannot predict or cause the past. Thus, according to Granger (1969), $X$ Granger causes $Y$ if past values of $X$ can be used to predict $Y$ more accurately than simply using the past values of $\mathrm{Y}$. The test is based on the following regressions:

$\mathrm{Y}_{\mathrm{t}}=\alpha_{0}+\sum_{-}(\mathrm{i}=1) \wedge n \alpha_{\mathrm{i}}^{\mathrm{y}} \mathrm{Y}_{\mathrm{t}-1} \sum_{\mathrm{i}=1}^{\mathrm{n}} \mathrm{Xt}-1 \alpha_{\mathrm{i}} \mathrm{x}+\mathrm{U}_{\mathrm{t}}$

$\mathrm{X}_{\mathrm{t}}=\beta_{0}+\sum_{-}(\mathrm{i}=1) \wedge \mathrm{n} \beta_{\mathrm{i}}^{\mathrm{y}} \mathrm{Y}_{\mathrm{t}-1} \sum_{\mathrm{i}=1}^{\mathrm{n}} \mathrm{Xt}-\mathrm{K} \beta_{\mathrm{i}} \mathrm{X}+\mathrm{Y}_{\mathrm{t}}$

Where $X_{t}$ and $Y_{t}$ are the variables to be tested while $U_{t}$ and $V_{t}$ are white noise disturbance terms. The null hypothesis $\alpha_{i}^{X}=\beta_{i}^{y}=0$ for all i's is tested against the alternative hypothesis $\alpha_{\mathrm{i}}^{\mathrm{X}} \neq 0$ and $\beta_{\mathrm{i}}^{\mathrm{Y}}=0$. If the co-efficient of $\alpha_{\mathrm{i}}^{\mathrm{X}}$ are statistically significant but that of $\beta_{\mathrm{i}}^{\mathrm{y}}$ are not, then $\mathrm{X}$ causes $\mathrm{Y}$. If the reverse is true, then $\mathrm{Y}$ causes $\mathrm{X}$. However, where both co-efficient of $\alpha_{\mathrm{i}}^{\mathrm{X}}$ and $\beta_{\mathrm{i}}^{\mathrm{y}}$ are significant then causality is bidirectional.

According Engle and Granger (1987), as a set of variables Yt is said to be co-integrated of der $(\mathrm{d}, \mathrm{b})$ denoted $\mathrm{Yt}=\mathrm{CI}(\mathrm{d}, \mathrm{b})$ if all components of $\mathrm{Yt}$ are integrated of order $\mathrm{d}$ or $\mathrm{b}$ (band $\mathrm{d}>0$ ) and there exists a vector $\left(\beta=\left(\beta_{1}, \beta_{2}, \ldots \beta_{n}\right)\right)$ such that a linear combination $\mathrm{Y} \beta Y_{t} \mathrm{i}=\left(\beta_{1} Y_{1 t}+\beta_{2} Y_{2 t}+\cdots, \beta_{\mathrm{n}} Y_{n t}\right.$ is not integrated of order (d,b). 


\section{Error Correction Mechanism (ECM)}

The next step is to estimate the equation using ordinary least square (OLS) technique. Having ascertained whether or not co-integration exists, then the next step requires the construction of error correction model to model dynamics relationship. The purpose of the error correction model is to indicate the speed of adjustment from the short-run equilibrium to the long-run equilibrium state. If co-integration is accepted, it suggests that the model is best specified in the first difference of its variables with one period lag of the residual $\{\mathrm{ECM}(-1)\}$ as an additional regressor.

The advantage of using error correction models (ECM) is that it incorporates the variables at both side levels and first differences and thus ECM captures the short run disequilibrium situations as well as the long-run equilibrium adjustments between variables (Mukhtar et al, 2007). Co-integration is a test for equilibrium between nonstationary variables integrated of the same order.

\section{Estimation and Data Analysis}

\section{Regression Analysis}

Table 1: table showing the log- regression of GDP on DSPT, EXDT, EXR, and FXR

\begin{tabular}{lllll}
\hline \multicolumn{2}{l}{$\begin{array}{l}\text { Dependent Variable: LOG(GDP) } \\
\text { Method: Least Squares }\end{array}$} & & & \\
Date: 04/07/17 Time: 01:45 & & & \\
Sample (adjusted): 2 31 & & & \\
Included observations: 30 after adjustments & Coefficient & Std. error & t-statistic & Prob. \\
\hline Variable & 1.466011 & 0.549959 & 2.665676 & 0.0133 \\
C & -0.182986 & 0.089572 & -2.042902 & 0.2517 \\
LOG(DSPT) & 0.318474 & 0.149948 & 2.123894 & 0.0438 \\
LOG(EXDT) & 0.771500 & 0.124214 & 6.211029 & 0.0000 \\
LOG(EXR) & 0.196990 & 0.089743 & 2.195055 & 0.0377 \\
LOG(FXR) & & & & \\
\hline \multicolumn{7}{c}{} & & & 4.745480 \\
\hline R-squared & 0.917519 & Mean dependent var & & 1.194539 \\
Adjusted R-squared & 0.904322 & S.D. dependent var & & 1.231184 \\
S.E. of regression & 0.369494 & Akaike info criterion & & 1.072357 \\
Sum squared resid & 3.413147 & Schwarz criterion & & 2.0314 \\
Log likelihood & -9.964714 & Hannan-Quinn criter. & & \\
F-statistic & 69.52464 & Durbin-Watson stat. & & \\
Prob(F-statistic) & 0,000000 & & & \\
\hline
\end{tabular}

Source: Eviews software 9

The table above shows the estimated model as

GDP=1.4660110.182986LOG(DSPT)+0.318474LOG(EXDT)+0.771500LOG(EXR+ $0.196990 \mathrm{LOG}(\mathrm{FXR})$

GDP and DSPT are inversely related, that is, a unit increase in DSPT will lead to $18.3 \%$ decrease in GDP which conforms to expectation. The $\mathrm{t}$-cal prob.value of 0.2517 that debt service payment has no significant effect on Nigeria's GDP. EXDT and GDP are positively related. A unit increases in EXRD will lead to an increase of $31.8 \%$ in GDP

Copyright () International Association of African Researchers and Reviewers, 2006-2017: www.afrrevjo.net.

Indexed African Journals Online: www.ajol.info 
which conforms to expectation. The t-cal prob.value of 0.0438 implies that external debt has significant effect on Nigeria's GDP.

EXR and FXR are also positively related with GDP which imp lies that increase in external reserve and foreign exchange will lead to $77.15 \%$ and $19.67 \%$ respectively increase in GDO. The t-cal prob-value of EXR which is 0.0000 and FXR which is 0.0517 indicates we reject the null hypothesis and accept that external reserve and exchange rate have significant relationship with GDP.

The adjusted coefficient of determination, $\mathrm{R}^{-2}$, shows that about $90.4 \%$ of the total variation in GDP is explained by DSPT, EXDT, EXR, and FXR. The remaining 9.6\% is due to error sources.

\section{Stationarity Test}

\begin{tabular}{|l|l|l|l|l|l|l|}
\hline & \multicolumn{3}{|l|}{ Augument Dickey Fuller (ADF) } & \multicolumn{2}{l|}{ Order of integration } \\
\hline Variables & Levels & \multicolumn{3}{|c|}{ Ist Diff } & \\
\hline & t-Stat. & p-value & t-stat. & p.value & & \\
\hline InGDP & -1.6326 & 0.3124 & -4.2146 & 0.0024 & $1(1)$ & \\
\hline InDSPT & 1.21656 & 0.7456 & -3.3456 & 0.0126 & $1(1)$ & \\
\hline InEXDT & -1.61384 & 0.3468 & -3.5464 & 0.0156 & $1(1)$ & \\
\hline InEXR & -1.24061 & 0.5676 & -3.3204 & 0.0317 & $1(1)$ & \\
\hline InFXR & -0.0654 & 0.8467 & -4.2146 & 0.0046 & $1(1)$ & \\
\hline
\end{tabular}

Table 2 Unit root test

$* *$ level of significance at $5 \% * * *$ level of significant at $1 \%$

Source: various computation from view 9

All the data are transformed into the natural log form. To determine the order of integration of the variables, the ADF (augmented Dickey-Fuller) test which the null hypothesis is $H_{0}=\beta=0$ (ie $\beta$ has a unit root), and the alternative hypothesis is $H_{l}=$ $\beta<0$ are implemented. The results for the level and differenced variables are presented in table 2 .

The stationarity tests were performed first in levels and then in first difference to establish the presence of unit roots and the order of integration in all the variables. The results of the ADF stationarity tests for each variable show that the tests fail to reject the presence of unit root for data series in level, indicating that these variables are nonstationary in levels. The first difference results show that these variables are stationary at $1 \%$ and 5\% significance level (integrated of order one 1(1)). As mentioned earlier, a linear combination of I (1) series could be I (0) if the series are cointegrated. We thus proceed to test for cointegration of the time series. 


\section{Lag Selection}

Endogenous variables: InGDP, InDSPT, InEXDT, InEXR, InFXR

\begin{tabular}{|c|c|c|c|c|c|c|}
\hline \multicolumn{7}{|c|}{ VAR Lag Order Selection Criteria } \\
\hline Lag & $\log \mathrm{L}$ & LR & FPE & AIC & $\mathrm{SC}$ & HQ \\
\hline 0 & -94.460 & NA & 0.000564 & 6.42567 & 6.60456 & 6.61024 \\
\hline 1 & 74.4617 & $261.20^{*}$ & $7.55 \mathrm{e}-0 *$ & $-2.2126^{*}$ & $-07656^{*}$ & $1.64354 *$ \\
\hline 2 & 93.46126 & 23.6024 & $1.26 \mathrm{E}-06$ & -1.7646 & 0.0567 & -1.04042 \\
\hline
\end{tabular}

Table 3: $\quad$ VAR lag order selection criteria

* indicates lag order selected by the criterion, LR: sequential modified LR test statistic (each test at 5\% level), FPE: Final prediction error, AIC: Akaike information criterion, SC: Schwarz information criterion, HQ; Hannan-Quinn information criterion.

From the table, our optimal using Akaike information criterion is lag1.

\section{Johansen Cointegration}

\begin{tabular}{|l|l|l|l|l|}
\hline Hypothesis & $\begin{array}{l}\text { Trace } \\
\text { Statistics }\end{array}$ & $\begin{array}{l}5 \% \text { critical } \\
\text { value }\end{array}$ & $\begin{array}{l}\text { Max. Eigen } \\
\text { value }\end{array}$ & $\begin{array}{l}5 \% \text { critical } \\
\text { value }\end{array}$ \\
\hline $\mathrm{r}=0$ & $75.604^{*}$ & 62.724 & $49.746^{*}$ & 35.764 \\
\hline $\mathrm{r} \leq 1$ & 36.764 & 46.946 & 16.246 & 26.542 \\
\hline $\mathrm{r} \leq 2$ & 20.641 & 27.646 & 11.426 & 20.242 \\
\hline $\mathrm{r} \leq 3$ & 7.624 & 16.226 & 7.642 & 13.342 \\
\hline $\mathrm{r} \leq 4$ & 0.221 & 4.246 & 0.221 & 4.246 \\
\hline
\end{tabular}

Table 4: Johansen cointegration result

*Level of significant at $10 \% * *$ level of significance at $5 \% * * *$ level of significant at $1 \%$

Source: computation from view 9

The results of the cointegration test, based on the Johansen cointegration approach are presented in table 4 . The author established lag 1 using akaike criterion (see table 3 ). Cointegration is tested on the long-run relationship between the dependent variable and independent variables. The table indicates that the test failed to accept the null hypothesis of no cointegration at 5\% level of significance. Both the trace and maximum Eigen value suggest that there is a common stochastic trend and as such the number of free random walks has been reduced by one. Therefore, GDP and independent variables have at least one common stochastic trend driving the relationship between them. The Johansen co-integration test shows this by cointegation test shows this by comparing the statistic values with this, there is at most 1 cointegrating equation in the model with both trace and maximum eigen value suggest 5\% significance level. This implies that an equilibrium relationship exists among the co-integrating variables. In addition, no matter the fluctuation in the short-run, these variables have the tendency to return to this equilibrium path in the long-run. 
Table 5: Parsimonious Error Correction Model

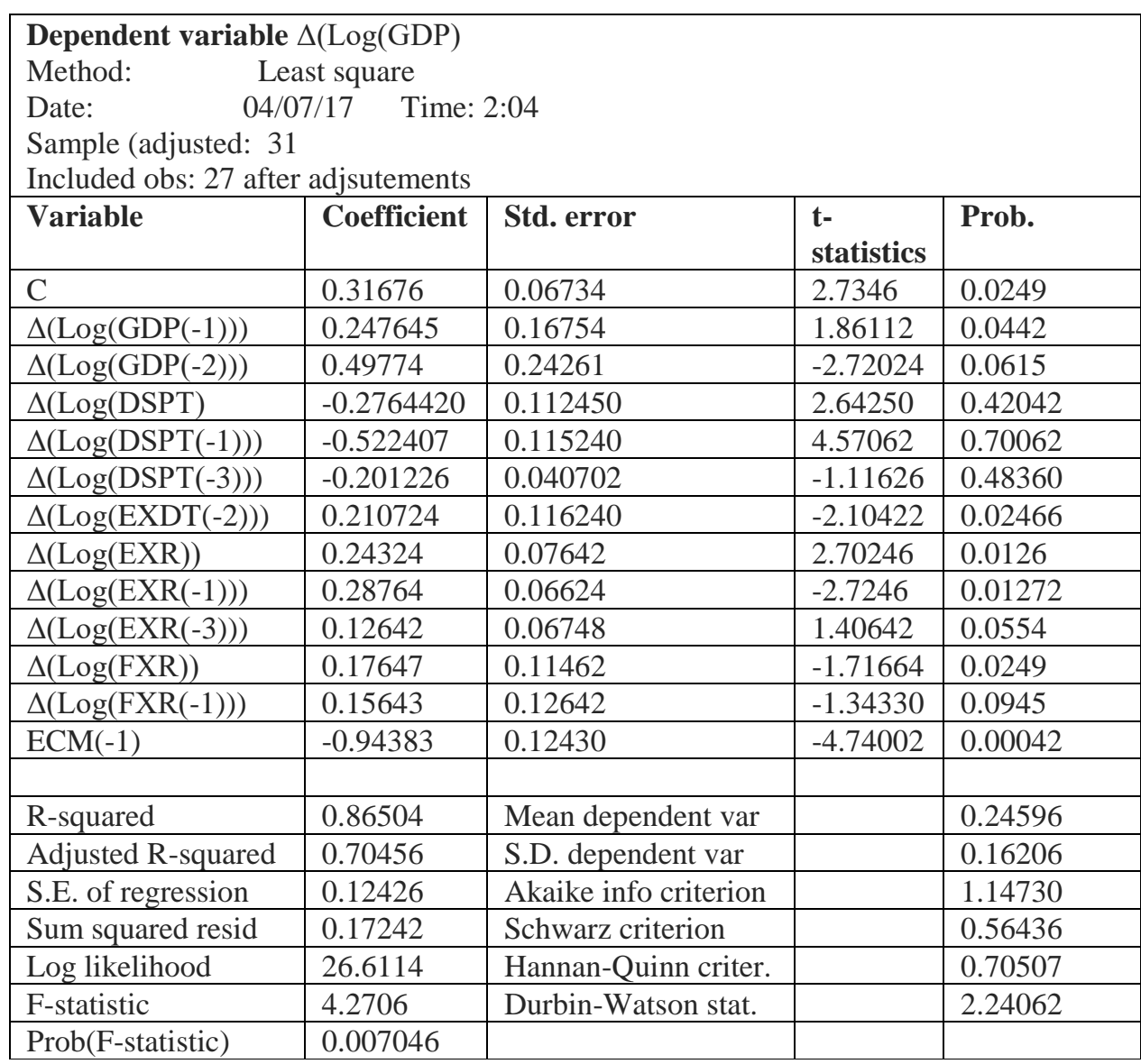

Source: computation from eview 9

Table 5 above presents results of parsimonious error correction model conducted to further analyse the long-run relationship between the variables and to capture the shortrun deviations of the parameters from the long-run equilibrium by incorporating period lagged residuals. The results show that external debt service (DSPT) is negative and insignificantly related to GDP. External debt stock is positive and significantly related to GDP. The control variables namely external reserve (EXR) and exchange rate (FXR) are positive and significantly related to GDP.

The Durbin- Watson statistic is approximately 2.24 indicating absence of autocorrelation in the model. The error correction coefficient is correctly signed and significant with value of -0.94383 . This shows that the speed of adjustment of the model one to any short-run shock is approximately 94.38 percent per annum. The Fstatistic is 4.2706 we therefore conclude that external debt impacts significantly on economic growth in Nigeria. 


\section{The Granger-Causality Test}

Table 6: Pairwise Granger Causality Tests

Date: 04/07/17 Time 01:52

Sample: 131

Lags: 2

\begin{tabular}{|l|l|l|l|}
\hline Null hypothesis & Obs & F-statistic & Prob. \\
\hline GDP does not Granger Cause DSPT & 29 & 1.88664 & 0.1734 \\
\hline DSPT does not Granger Cause GDP & & 0.01120 & 0.9889 \\
\hline GDP does not Granger Cause EXDT & 29 & 3.78545 & 0.0372 \\
\hline EXDT does not Granger Cause GDP & & 0.14160 & 0.8687 \\
\hline GDP does not Granger Cause EXR & 29 & 2.07746 & 0.1472 \\
\hline EXR does not Granger Cause GDP & & 0.01120 & 0.9889 \\
\hline GDP does not Granger Cause FXR & 29 & 2.84358 & 0.0788 \\
\hline FXR does not Granger Cause GDP & & 7.60077 & 0.0029 \\
\hline
\end{tabular}

Source: E Views software

From the table above, it can be said that there is no causality relationship between external debt service and GDP. There is however unidirectional causality relationship with external debt and GDP running from GDP. Furthermore, there is no causality relationship between GDP and external reserve. The result however shows a unidirectional causality relationship between exchange rate and GDP.

\section{Discussion of Findings}

From the result of the analysis, it was observed that debt service payment is negatively related with GDP. This agrees with the apriori expectation since debt service payment, being a resource drain exercise, is expected to be negatively related with economic growth. The t-cal prob.value which was found to be 0.0517 indicates that there is no significant relationship between the variables. The error correction test further indicates that there is no long run relationship between external debt service and GDP. This agrees with the theory of debt overhang which states that if there is some likelihood that in future, debt will be larger than the country's repayment ability, expected debtservice cost will discourage further domestic and foreign investment and thus harm growth (Bovensztem, 1990). The negative effect of this finding also supports earlier studies by Clements, Bhattacharya \& Nguyen (2003) Frankal \& Dude (1989).

The findings also reveal that external debt is positively related with GDP as indicated by its coefficient $(0.318474)$. The $t$-cal prob.value at 0.438 shows that external debt significantly impacted on Nigeria's economic growth. This result was further supported by the error correction test which found a long run relationship between the two. The findings therefore support apriori expectation as external debt is expected to be either positively or negatively related with economic growth depending on the usage of such external debt. Earlier studies by Ezike and Mojekwu (2011) and Solomon (2016) have also found that external debt use in Nigeria impacted on its economic growth thus supporting the present findings.

Findings show a positive relationship between external reserves and economic growth while the t-cal prob. value at 0.000 implies that growth in external reserve significantly impacts on Nigeria's economic growth.

Copyright (C) International Association of African Researchers and Reviewers, 2006-2017: www.afrevjo.net.

Indexed African Journals Online: www.ajol.info 
The study also shows a positive relationship between foreign exchange rate and GDP which implies that the management of debt by way of debt service payment tends to affect exchange rate, which in turn affects economic growth. The t-cal prob.value of 0.0377 indicates that there is significant relationship, with the Error correction test confirming a long run relationship between exchange rate and GDP.

Findings reveal that there is no significant causality relationship between external debt service and GDP. there is however a unidirectional causality relationship between external debt and GDP running from GDP.

\section{Conclusion}

Based on the overall results of the study, the following conclusions are reached.

1) Debt service payment has negative effect on Nigeria's GDP.

2) External debt has positive and significant effect on Nigeria's economic growth.

3) External debt has long-run significant effect on economic growth.

4) There is a unidirectional causality relationship between external debt and economic growth while external debt service has no significant causal relationship with growth index.

\section{Recommendations}

From the findings and conclusion above, this study provided the following recommendations for policy makers, government agencies and appropriate authority for action

1. External debt should be used for the purpose for which it was borrowed and such should be on basic and infrastructural development that will help improve on the business environment and economic output making for ease of repayment.

2. Debt management policy should be properly initiated to reduce the negative effect of debt service on the economy as shown in the findings.

3. Efforts should be geared towards diversifying the economy and government revenue as this will help reduce the use of external loan to fund government projects.

4. There is need to strengthen the naira, therefore authorities should adopt policies that will encourage foreign investment and reduce demand for foreign good

5. Development activities in Nigeria should be financed through increased export earnings spearheaded by export-led-growth strategy as well as investment in human capital as these would be the best alternative to external debt in the longrun

Copyright $\odot$ International Association of African Researchers and Reviewers, 2006-2017: www.afrrevjo.net. 
AFRREV VOL. 11 (4), S/NO 48, SEPTEMBER, 2017

\section{APPENDIX I}

External debt service payment, external debt, external reserve, foreign exchange rate and Gross Domestic Product (1985-2015)

\begin{tabular}{|c|c|c|c|c|c|}
\hline Year & DSPT (N'b) & $\begin{array}{l}\text { EXDT } \\
\left(N^{\prime} m\right)\end{array}$ & $\operatorname{EXR}\left(N^{\prime} b\right)$ & $\mathrm{FXR}(\mathrm{N} / \$ 1)$ & $\left.\ddagger^{\prime} b\right)$ \\
\hline 1985 & 1.500700 & 18.65500 & 1.892 & NA & 28.874 \\
\hline 1986 & 1.278600 & 22.21600 & 1.350 & 2.0200 & 20.721 \\
\hline 1987 & 0.740000 & 29.02500 & 1.498 & 4.0200 & 24.093 \\
\hline 1988 & 1.581900 & 29.62400 & 0,933 & 4.5400 & 23.272 \\
\hline 1989 & 1.278200 & 30.12200 & 2.041 & 7.3900 & 24.231 \\
\hline 1990 & 3.572400 & 33.45800 & 4.129 & 8.0400 & 30.757 \\
\hline 3991 & 3.435000 & 33.52700 & 4.678 & 9.9100 & 27.393 \\
\hline 1992 & 2.392600 & 28.97900 & 1.196 & 17.3000 & 29.301 \\
\hline 1993 & 1.772500 & 30.69900 & 1.649 & 22.0500 & 15.789 \\
\hline 1994 & 1.843000 & 29.40000 & 1.700 & 21.8900 & 18.086 \\
\hline 1995 & 1.620600 & 32.60000 & 1.400 & 81.2000 & 28.547 \\
\hline 1996-01-01 & 1.876600 & 28.06000 & 4.100 & 21.8861 & 140.930 \\
\hline 1997-01-01 & 1.496600 & 27.08780 & 7.600 & 21.8861 & 144.880 \\
\hline 1998-01-01 & 1.272540 & 28.77354 & 7.100 & 21.8861 & 148.820 \\
\hline 1999-01-01 & 1.724900 & 28.03921 & 5.500 & 93.3917 & 149.520 \\
\hline 2000-01-01 & 1.716010 & 28.27368 & 9.900 & 102.2408 & 157.470 \\
\hline 2001-01-01 & 2.128170 & 28.34700 & 10.400 & 111.9958 & 164.420 \\
\hline 2002-01-01 & 1.168400 & 30.99187 & 7.700 & 121.8892 & 170.640 \\
\hline 2003-01-01 & 1.809280 & 32.91681 & 7.500 & 129.7642 & 188.310 \\
\hline 2004-01-01 & 1.754750 & 35.94466 & 17.000 & 133.3267 & 251. -840 \\
\hline 2005-01-01 & 8.807000 & 20.47797 & 28.300 & 131.5892 & 260.520 \\
\hline 2006-01-01 & 6.727840 & 3.544490 & 42.300 & 128.6008 & 281.910 \\
\hline 2007-01-01 & 0.910895 & 3.654210 & 51.300 & 125.5150 & 301.160 \\
\hline 2008-01-01 & 0.460728 & 3.720360 & 53.000 & 119.0533 & 320.040 \\
\hline 2009-01-01 & 0.428040 & 3.947300 & 42.400 & 148.8867 & 342.230 \\
\hline 2010-01-0! & 0.354415 & 4.534190 & 32.300 & 150.2980 & 369.060 \\
\hline 2011-01-01 & 0.351619 & 5.633710 & 32.300 & 153.8616 & 387.100 \\
\hline 2012-01-01 & 0.293003 & 6.527070 & 32.600 & 157.5000 & 403.670 \\
\hline 2013-01-01 & 0.297329 & 8.821900 & 43.800 & 157.2700 & 425,440 \\
\hline 2014-01-01 & 0.346723 & 9.711450 & 34.200 & 169.6800 & 452.280 \\
\hline 2015-01-01 & 0.331059 & 10.71843 & 28.300 & 196.9900 & 464.280 \\
\hline
\end{tabular}

Source: Debt Management Office, CBN Statistical Bulletin, 2015 


\section{References}

Adejuwon, K. D., James, K. S., \& Adebayo, O. S. (2010). Debt burden and Nigerian development. Journal of Business and Organizational Development, 2:102112

Adesola, W. A. (2009). Debt Servicing and economic growth in Nigeria: An Empirical investigation. Global Journal of Social Sciences, 8(2). Retrieved from www.globaljournalseries.com.

Ajayi, K. (2010). International administration and economic relations in a changing World. Ilorin: Majab Publishers.

Borensztein, E. (1990). Debt overhang, debt reduction and investment: The case of the Philippines. International Monetary Fund Working Paper No. WP/90/77, September 30

Central Bank of Nigeria (CBN) Statistical Bulletin, various Issues.

Clements, B., Bhattacharya, R. \& Nguyen, T. Q. (2003). External debt, public investment, and growth in low-income countries. International Monetary Fund (IMF) Working Paper WP/03/249, December.

Ekperiware, M.C., Oladeji, S.I. (2012). External debt relief and economic growth in Nigeria. American Journal of Economics.

Emmanuel, O. O. (2012). An empirical analysis of the impact of public debt on economic growth; Evidence from Nigeria 1975-2005. Canadian Social Science, 8(4), pp.154-161.

Ezeabasili, V.N., Isu, H.O., Mojekwu, J. N., (2011). Nigeria's external debt and economic growth: An error correction approach. International Journal of Business and Management. 6 (5), May.

Ezike, J. E. \& Mojekwu. J. N. (2011). The impact of external debt on macro-economic performance. International Journal of Business and Management Tomorrow., $1(2), 1-12$.

Frankal, J. A. \& Dude, M. P. (1989). Analytical issues in debt. International Monetary Fund (IMF) Washington Publishers, 10-32.

Hameed. A. Ashraf, H. \& Chaudhary, M.A. (2013) External debt and its impact on. International Research Journal of Finance and Economics, 20.

Hassan, O.M., Sule, A. and Abu, J. (2015). Implications of external debt on the Nigerian economy: Analysis of the dual gap theory. Journal of Economics and Sustainable Development, 6 (13), 238-248.

Ibi, E. E. \& Aganyi, A. (2015), Impacts of external debt on economic growth in Nigeria: a VAR approach. Journal of Business Management and Administration, 3(1), $1-5$.

Matthew, A. \& Mordecai, B.D. (2016). The impact of public debt on economic development of Nigeria. Asian Research Journal of Arts \& Social Sciences, 1(1), 1-16.

Copyright () International Association of African Researchers and Reviewers, 2006-2017: www.afrrevjo.net.

Indexed African Journals Online: www.ajol.info 
Nzekwu, J. A. (2011). Emerging challenges for debt management and investor offices. Central Bank of Nigeria ww-w.centralbanking.com/debtmanagement.

Nwanne, T. F. I. \& Eze, O. R. (2015). Assessing the effect of external debt servicing and receipt on exchange rate in Nigeria. International Journal of Economics and Finance, 7(9), pp.278-286.

Obademi, O.E. (2013). External Debt and Nigeria's economic growth nexus, matters arising. Journal of poverty, Investment and Development-An open access international Journal, 12013.

Okoli, O.R. (2014). External debt crisis, debt relief and economic growth: Lessons from Nigeria. European Journal of Business and Management, 6 (33).

Solomon, O. (2016). The impact of external debt on the Nigerian economy. www. independent, academia. Edu

Soludo, C, C. (2003). Debt, Poverty and Inequality: Towards an exit strategy for Nigeria and Africa, CBN Economic and Financial Review, 24 (4),

Todaro MP (2003). Economic Development. $\mathrm{S}^{1}$ Edition, New Delhi: Pearson Education.

Udoffia, D, T. \& Akpanah, E. A. (2016). An assessment of the impact of external debt on economic growth of Nigeria. International Journal of Social Sciences, $10(1), 1-27$.

Udoka, C.O. \& Ogege, S. (2012). Public debt and the crisis of development in Nigeria econometric investigation. Asian Journal of Finance and Accounting, 4(2), 231-243. 